\title{
Detection of activated K-ras in non-small cell lung cancer by membrane array: A comparison with direct sequencing
}

\author{
INN-WEN CHONG ${ }^{1 *}$, MEI-YIN CHANG ${ }^{2 *}$, CHAU-CHYUN SHEU ${ }^{1}$, CHENG-YUAN WANG $^{1}$, \\ JHI-JHU HWANG ${ }^{1}$, MING-SHYAN HUANG ${ }^{1}$ and SHIU-RU LIN ${ }^{3,4}$ \\ ${ }^{1}$ Division of Pulmonary and Critical Care Medicine, Kaohsiung Medical University Hospital, Kaohsiung Medical University; \\ ${ }^{2}$ Graduate Institute of Medicine, ${ }^{3}$ Graduate Institute of Medical Genetics, College of Medicine, Kaohsiung Medical \\ University; ${ }^{4}$ BioMedi Innovation Incubation Center, Kaohsiung Medical University, Kaohsiung 807, Taiwan, R.O.C.
}

Received November 30, 2006; Accepted January 2, 2007

\begin{abstract}
The ability to detect K-ras oncogene may provide additional information for the management of patients with non-small cell lung cancer (NSCLC). In the present study, we detected the K-ras oncogene in 76 patients with NSCLC by two methods: direct sequencing of K-ras in tumor tissues and membrane array detection of the gene overexpression specific for activated K-ras in peripheral blood. The results showed that $28(36.8 \%)$ of the 76 Taiwanese NSCLC patients had K-ras mutations, with a frequency of $36.4 \%$ (20/55) in adenocarcinomas and $38.1 \%(8 / 21)$ in squamous cell carcinomas. The K-ras mutations were more frequently found in smokers than in non-smokers (51.4 vs. $24.4 \%, \mathrm{P}=0.015)$. The incidences of K-ras mutation in the subgroups of non-smokers and squamous cell carcinomas are relatively higher in Taiwan than in other countries. On the other hand, the membrane array method could positively detect circulating activated K-ras in all of the 27 NSCLC patients with K-ras mutations at codons 12,13 and 61 , and in 4 of the 48 patients with wild-type K-ras. Our results suggest that the K-ras oncogene membrane array serves as a sensitive and convenient tool for the detection of K-ras oncogene, and therefore, has a great potential for clinical applications.
\end{abstract}

\section{Introduction}

Lung cancer is the leading cause of cancer deaths worldwide. After decades of extensive research to improve the diagnosis and treatment for lung cancer, its prognosis remains unsatisfactory. The average 5-year survival of patients with

Correspondence to: Dr Shiu-Ru Lin, Department of Laboratory Medicine, Graduate Institute of Medical Genetics, College of Medicine, Kaohsiung Medical University, Kaohsiung 807, Taiwan, R.O.C.

E-mail:shruli@kmu.edu.tw

${ }^{*}$ Contributed equally and should be regarded as the first authors

Key words: direct sequencing, K-ras, membrane array, mutation, non-small cell lung cancer, tumor markers lung cancer is only $15 \%$ (1). Recently, molecular technology has been largely used for the understanding of tumorigenesis of lung cancer. It was hopeful that the applications of such molecular approaches in the clinical management of lung cancer, including early diagnosis, risk stratification, and even the guidance of individualized anti-cancer therapy, could further improve the survival rate for this malignancy.

The Ras proteins play an important role in cellular signal transduction, which regulates cell functions such as growth, differentiation, angiogenesis and survival. Mutational activation of Ras oncogenes is found in approximately $30 \%$ of all human cancers (2). Three human Ras genes have been identified: $\mathrm{H}$-ras, K-ras and N-ras. Mutations of K-ras, the most frequently mutated gene of the Ras family, are predominantly found in pancreatic cancer, colorectal cancer and lung cancer; N-ras mutations are predominantly found in melanomas and acute leukemias; while H-ras mutations are rare (3). According to the serial studies of K-ras oncogene in human lung cancer by Rodenhuis et al (3-7), K-ras mutations are detected in 15-20\% of non-small cell lung cancer (NSCLC), and particularly, 30$50 \%$ of adenocarcinomas. In total $80 \%$ of K-ras mutations occur in codon 12, others are located in codons 13 and 61. The majority of the point mutation is G-T transversion. They also found that exposure to carcinogenic agents in tobacco smoke is an important factor in the induction of point mutations in K-ras in lung adenocarcinomas. The accumulating evidence suggests that mutational activation of K-ras is an adverse prognostic factor for lung cancer $(8,9)$. Recently, K-ras was investigated as a target for cancer therapy. Several therapeutic agents have been developed by means of inhibition of the Ras protein expression, inhibition of K-ras processing, targeting mutant K-ras protein or targeting Ras effectors (2). Therefore, it is expected that the ability to detect activated K-ras may provide additional diagnostic, prognostic and therapeutic information for the management of patients with NSCLC.

Conventionally, detection of activated K-ras oncogene depends on identifying K-ras mutations in tumor tissues. However, activation of K-ras oncogene is not exclusively associated with K-ras mutation. Studies have shown that in the absence of activating mutations, K-ras may still play a role in oncogenesis via Ras gene amplification, overexpression or upstream activation of the pathway (10-13). Since the activation of K-ras 
Table I. Nucleotide sequences of primers used for PCR and DNA sequencing.

Sequences

PCR product (bp)

$\begin{array}{ll}\text { Exon } 1 & \\ \text { Forward } & \text { 5'-TAATACGACTCACTATAGGGAGATATGTTGAGGGCCCATCTC' } \\ \text { Reverse } & \text { 5'-TCCTAGGTCAGCGCAACCAAAT-3' } \\ \text { Exon } 2 & \\ \text { Forward } & \text { 5'-TAATACGACTCACTATAGGGTTCCTACAGGAAGCAAGTAG-3' } \\ \text { Reverse } & \text { 5'-CACAAAGAAAGCCCTCCCCA-3' } \\ \text { Sequencing primer } & \text { 5'-CCCTATAGTGAGTCGTATTA-3' }\end{array}$

initiates cellular signaling cascades, which further result in overexpression of the downstream genes, and, moreover, recent advances in molecular technology have allowed us to detect very small amounts of gene overexpression in blood, an easier and effective blood-based test for the detection of gene overexpression specific for activated K-ras is proposed. In our previous studies, we employed the microarray technique combined with bioinformatics tools to screen all differentially expressed genes after activated K-ras oncogene in human adrenocortical cells transfected with a K-ras mutant, and determined 22 potential gene targets. Then, a membrane array blotted with these 22 gene probes was constructed and applied to test the peripheral blood samples from patients with various cancers. The results demonstrated that the K-ras oncogene membrane array had a remarkable potential to detect activated $\mathrm{K}$-ras in human cancers (14-17).

In the present study, we not only detected the K-ras mutations by direct sequencing of the K-ras gene in tumor tissues from 76 patients with NSCLC, but also detected activated K-ras oncogene in their peripheral blood samples by using the membrane array method. The primary aim of this study was to evaluate the efficacy of the blood test with $\mathrm{K}$-ras oncogene membrane array for the detection of activated K-ras in NSCLC patients. We also intended to explore the spectrum of K-ras mutation in NSCLC patients in Taiwan. The correlations between the activated K-ras and the clinicopathological features of NSCLC patients were also analyzed.

\section{Materials and methods}

Patients and specimen collection. The study was approved by the Institutional Review Board of Kaohsiung Medical University Hospital. Seventy-six patients of pathology-proven NSCLC who had undergone surgical resection or biopsy between January 2004 and December 2005, and 20 normal persons were enrolled in this study. Written informed consents were obtained from all subjects prior to sample collection. Five milliliters of peripheral blood were collected with test tubes containing anticoagulant sodium citrate from each of the enrolled patients before receiving any tumor manipulations (i.e., aspiration, biopsy or surgical resection) and any anticancer treatment, and from normal persons during health examinations. To avoid the contamination of skin cells, the sampled blood was taken via an intravenous catheter, and the first few milliliters of blood were discarded. Total-RNA was immediately extracted from the peripheral whole blood, and then served as templates for cDNA synthesis. Surgically removed tumor tissues were frozen in liquid nitrogen immediately after surgical resection and stored at $-80^{\circ} \mathrm{C}$ until analysis. Complete staging procedures including chest radiography, bronchoscopy, brain and thoracic computed tomography, sonography, and bone scintigraphy were carried out to precisely determine the characteristics of primary tumor $(\mathrm{T})$, nodal involvement $(\mathrm{N})$ and metastasis (M) in the NSCLC patients according to the revised international system for staging lung cancer (18).

DNA and total-RNA extraction. Genomic DNA was isolated from the surgically removed tumor tissues using proteinase-K (Stratagene, La Jolla, CA) digestion and phenol/chloroform extraction procedure according to the method by Sambrook (19). Total-RNA was extracted from the peripheral whole blood with Isogen ${ }^{\mathrm{TM}}$ (Nippon Gene Co., Ltd., Toyoma, Japan) according to the manufacturer's instructions. RNA isolates were then analyzed by using a spectrophotometer (Beckman, DU800, USA) at wavelengths of 260/280 nm, and those with $260 / 280 \mathrm{~nm}$ absorption ratio $>1.8$ were immediately subjected to cDNA synthesis. Poly(A)+enriched RNA was purified from total-RNA by using Dynabeads ${ }^{\circledR}$ mRNA Direct ${ }^{\mathrm{TM}}$ kit (Dynal A.S., Oslo, Norway). Then, $2 \mu \mathrm{g}$ of Poly(A) ${ }^{+}$RNAs from each sample was subjected to double-strand cDNA synthesis by using the Smart ${ }^{\mathrm{TM}}$ PCR cDNA synthesis kit (Clontech, Palo Alto, CA, USA) according to the manufacturer's protocol.

Direct sequencing. To identify mutations of the K-ras gene, polymerase chain reaction (PCR) analysis was performed. The oligonucleotide primers for exons 1 and 2 were used (Table I). Briefly, the PCR amplification of DNA samples (20 ng) was carried out in a $50 \mu 1$ reaction volume with a final concentration of 1X PCR buffer [10 mmol/1 Tris- $\mathrm{HCl}(\mathrm{pH} 8.3)$, $1.5 \mathrm{mmol} / 1 \mathrm{MgCl}_{2}, 50 \mathrm{mmol} / 1 \mathrm{KCl}$, and $0.01 \%$ gelatin], $100 \mathrm{mmol} / \mathrm{l}$ deoxynucleotide triphosphate (Promega), and $5 \mathrm{U}(1 \mathrm{U} / \mu \mathrm{l})$ of BioTools DNA polymerase (Biotechnological and Medical Laboratories, S.A., Madrid, Spain) for each reaction. The PCR products were purified by the QIAEX II gel extraction kit (Qiagen Inc., Valencia, CA, USA) and then subjected to sequencing using a double-stranded cycle sequencing system (Gibco-BRL, Gaithersburg, MD). The 
Table II. Oligonucleotide probe sequences used for membrane array assays.

\begin{tabular}{|c|c|c|}
\hline Symbol & Name & Oligonucleotide sequence of probe \\
\hline ATP2A2 & $\begin{array}{l}\text { Homo sapiens ATPase, } \mathrm{Ca}^{++} \text {transporting, } \\
\text { cardiac muscle, slow twitch } 2\end{array}$ & $\begin{array}{l}\text { 5'-ACCCGGACTTTGAAGGCGTGGATTGTGCAATCTTTG } \\
\text { AATCCCCATACCCG-3' }\end{array}$ \\
\hline ATP6V0B & $\begin{array}{l}\text { Homo sapiens ATPase, } \mathrm{H}^{+} \text {transporting, } \\
\text { lysosomal } 21 \mathrm{kDa}, \mathrm{V0} \text { subunit } \mathrm{c}^{\prime}\end{array}$ & $\begin{array}{l}\text { 5'-CATCGGCCATCGGAACTACCATGCAGGCTACTCCAT } \\
\text { GTTTGGGGCT-3' }\end{array}$ \\
\hline BCL2 & B-cell CLL/lymphoma 2 & $\begin{array}{l}\text { 5'-ACAACATCGCCCTGTGGATGACTGAGTACCTGAACC } \\
\text { GGCACCTGCACA-3' }\end{array}$ \\
\hline CALM2 & Homo sapiens calmodulin 2 & $\begin{array}{l}\text { 5'-GAAGCATTCCGTGTGTTTGATAAGGATGGCAATGGC } \\
\text { TATATTAGTGCTGCAGAACTTCG-3' }\end{array}$ \\
\hline CEBPB & $\begin{array}{l}\text { Homo sapiens CCAAT/ } \\
\text { enhancer binding protein, } B\end{array}$ & $\begin{array}{l}\text { 5'-CCGCCTGCCTTTAAATCCATGGAAGTGGCCAACTTC } \\
\text { TACTACGAGGCGGA-3' }\end{array}$ \\
\hline COL4A1 & Homo sapiens collagen, type IV, $\alpha 1$ & $\begin{array}{l}\text { 5'-GCAAATGTGACTGCCATGGAGTGAAGGGACAAAAG } \\
\text { GGTGAAAGAGGCCTC-3' }\end{array}$ \\
\hline CXCL11 & $\begin{array}{l}\text { Homo sapiens chemokine } \\
\text { (C-X-C motif) ligand } 11\end{array}$ & $\begin{array}{l}\text { 5'-GTTCAAGGCTTCCCCATGTTCAAAAGAGGACGCTGT } \\
\text { CTTTGCATAGGCCC-3' }\end{array}$ \\
\hline CXCR4 & $\begin{array}{l}\text { Homo sapiens chemokine } \\
\text { (C-X-C motif) receptor } 4\end{array}$ & $\begin{array}{l}\text { 5'-CСССАТССТCTATGCTTTCCTTGGAGCCAAATTTAAA } \\
\text { ACСТCTGCCCAGCAC-3' }\end{array}$ \\
\hline CYR61 & $\begin{array}{l}\text { Homo sapiens cysteine-rich, } \\
\text { angiogenic inducer, } 61\end{array}$ & $\begin{array}{l}\text { 5'-CAGCAGCCTGAAAAAGGGCAAGAAATGCAGCAAGA } \\
\text { CCAAGAAATCCCCCG-3' }\end{array}$ \\
\hline DVL3 & $\begin{array}{l}\text { Homo sapiens disheveled, } \\
\text { dsh homolog } 3 \text { (Drosophila) }\end{array}$ & $\begin{array}{l}\text { 5'-CGTCACCTTGGCGGACTTTAAGGGCGTTTTGCAGCG } \\
\text { ACCCAGCTATAAGT-3' }\end{array}$ \\
\hline $\mathrm{E} 2 \mathrm{~F} 4$ & $\begin{array}{l}\text { Homo sapiens E2F transcription } \\
\text { factor } 4, \mathrm{p} 107 / \mathrm{p} 130 \text {-binding }\end{array}$ & $\begin{array}{l}\text { 5'-TGAGATCACAGTGAGTGGCGGCCCTGGGACTGATA } \\
\text { GCAAGGACAGT-3' }\end{array}$ \\
\hline ETS1 & $\begin{array}{l}\text { Homo sapiens v-ets erythroblastosis virus } \\
\text { E26 oncogene homolog } 1 \text { (avian) }\end{array}$ & $\begin{array}{l}\text { 5'-TGGAGCAGCCAGTCATCTTTCAACAGCCTGCAGCGT } \\
\text { GTTCCСTCCTATGA-3' }\end{array}$ \\
\hline H2AFZ & $\begin{array}{l}\text { Homo sapiens } \mathrm{H} 2 \mathrm{~A} \text { histone family, } \\
\text { member } \mathrm{Z}\end{array}$ & $\begin{array}{l}\text { 5'-CGTGGAGATGAAGAATTGGATTCTCTCATCAAGGCT } \\
\text { ACAATTGCTGGTGGTGGTGTC-3' }\end{array}$ \\
\hline L1CAM & $\begin{array}{l}\text { Homo sapiens } \mathrm{L} 1 \text { cell } \\
\text { adhesion molecule }\end{array}$ & $\begin{array}{l}\text { 5'-CCTTCCTGGTGGTGTCCAACACGTCCACCTTCGTGCC } \\
\text { CTATGAGATCAAA-3' }\end{array}$ \\
\hline LRP1 & $\begin{array}{l}\text { Homo sapiens low density } \\
\text { lipoprotein-related protein } 1\end{array}$ & $\begin{array}{l}\text { 5'-ATGCCTGTGAAAACGACCAGTATGGGAAGCCGGGT } \\
\text { GGCTGCTCTGACAT-3' }\end{array}$ \\
\hline MMP1 & Matrix metallopeptidase 1 & $\begin{array}{l}\text { 5'-AAGTGACTGGGAAACCAGATGCTGAAACCCTGAAG } \\
\text { GTGATGAAGCAGCCC-3' }\end{array}$ \\
\hline RAP1B & $\begin{array}{l}\text { Homo sapiens RAP1B, member } \\
\text { of RAS oncogene family }\end{array}$ & $\begin{array}{l}\text { 5'-GGAAGATGAAAGAGTTGTAGGGAAGGAACAAGGTC } \\
\text { AAAATCTAGCAAGACAATGGAACAACTGTG-3' }\end{array}$ \\
\hline RPL30 & $\begin{array}{l}\text { Homo sapiens ribosomal } \\
\text { protein L30 }\end{array}$ & $\begin{array}{l}\text { 5'-GCTCCAACTCGTTATGAAAAGTGGGAAGTACGTC } \\
\text { CTGGGGTACAAGCAGAC-3' }\end{array}$ \\
\hline SLC25A5 & $\begin{array}{l}\text { Homo sapiens solute carrier } \\
\text { family } 25, \text { member } 5\end{array}$ & $\begin{array}{l}\text { 5'-TCTGATGGGATTAAGGGCCTGTACCAAGGCTTTAAC } \\
\text { GTGTCTGTG }\end{array}$ \\
\hline SPP1 & Homo sapiens secreted phosphoprotein 1 & $\begin{array}{l}\text { 5'-GTGGACAGCCAGGACTCCATTGACTCGAACGACTCT } \\
\text { GATGATGTAGATGAC-3' }\end{array}$ \\
\hline TAF12 & $\begin{array}{l}\text { Homo sapiens TAF12 RNA } \\
\text { polymerase II }\end{array}$ & $\begin{array}{l}\text { 5'-CAGCACCCCTCCACAAGGCTCCATGGCCAATAGTAC } \\
\text { TGCAGTGGTAAAGA-3' }\end{array}$ \\
\hline TBX19 & Homo sapiens T-box 19 & $\begin{array}{l}\text { 5'-TCATCTGCTCAATGTGGTGGAGAGTGAGCTTCAGGC } \\
\text { AGGGAGGGAAAAAG-3' }\end{array}$ \\
\hline B-actin & & $\begin{array}{l}\text { 5'-TGCATTGTTACAGGAAGTCCCTTGCCATCCTAAAAG } \\
\text { CCACСCCACTTCTCTCTAAGGAGA-3' }\end{array}$ \\
\hline
\end{tabular}


purified products were then sequenced directly with a T7 promoter/IRD800 (LI-COR, Lincoln, NE), which is a T7 promoter primer (Table I) labeled with a heptamethine cyanine dye, or using DNA polymerase incorporating IRD-labeled dATP for sequencing reaction. Upon completion of the sequencing reaction, $4 \mu 1$ of formamide loading buffer was added to the reaction mixture, and the sample was heated to $95^{\circ} \mathrm{C}$ for $5 \mathrm{~min}$, snap cooled and loaded onto the sequencing gel.

An automated DNA electrophoresis system (Model 4200; LI-COR) with a laser diode emitting at $785 \mathrm{~nm}$ and fluorescence detection between 815 and $835 \mathrm{~nm}$ was used to detect and analyze the sequencing ladder. Electrophoresis was performed on a $41 \mathrm{~cm}$ x $25 \mathrm{~cm}$ x $0.2 \mathrm{~mm}$ gel consisting of $6 \%$ Long Ranger gel matrix (AT Biochem; Malvern, PA) with $7 \mathrm{M}$ urea and a running buffer consisting of $133 \mathrm{mM}$ Tris base, $44 \mathrm{mM}$ boric acid and $2.5 \mathrm{mM}$ EDTA, pH 9.0 at $50^{\circ} \mathrm{C}$. From each sequencing reaction, $1.5 \mu \mathrm{l}$ of the sample was loaded on each lane. Following the loading of samples, electrophoresis was carried out at a constant voltage of $2000 \mathrm{~V}$ with the gel heated to $50^{\circ} \mathrm{C}$. Data collection and image analysis was performed by an IBM486 (Model 90) using the Base Image IR software supplied with the model 4200 DNA sequencer.

Membrane array analysis. The design and preparation of membrane array was based on our previous study (17). Briefly, OMP3 (Oligonucleotide Modeling Platform, DNA Software) was used to design the probe sequences for the 22 target genes (Table II). The newly synthesized oligonucleotide fragments were dissolved in DI water to a concentration of $20 \mathrm{mM}$ and then applied to a Biojet Plus 3000 nanoliter dispense system (BioDot Inc., Irvine, CA, USA), which blotted the 22 target genes, one housekeeping gene ( $ß$-actin), and one nonmammalian plant gene $(50 \mathrm{nl}$ per spot and $1.5 \mathrm{~mm}$ between spots) on Nytran ${ }^{\circledR}$ SuperCharge nylon membrane (Schleicher \& Schuell, Keene, NH) in triplicate. DMSO was also dispensed onto the membrane as a blank control. On the other hand, first-strand cDNA targets for hybridization were produced by reverse transcription of mRNAs from the peripheral whole blood of 76 NSCLC patients and 20 healthy volunteers in the presence of digoxigenin (DIG)-labeled UTP (Roche Diagnostics GmbH, Penzberg, Germany). The DIG-labeled cDNA was added to the ExpressHyb Hybridization Solution (BD Biosciences, Palo Alto, CA, USA) to form the hybridization mixture. Hybridization was carried out at $42^{\circ} \mathrm{C}$ for $12 \mathrm{~h}$ in a humid chamber. After hybridization, the membrane arrays were washed, blocked, and then incubated for $30 \mathrm{~min}$ in antibody solution containing alkaline phosphatase-conjugated anti-DIG antibody (Roche Diagnostics). Color development was carried out by incubating the hybridized membranes in a chromogen solution containing nitroblue tetrazolium chloride and 5-bromo-4-chloro-3-indolyl-phosphate (NBT/BCIP) for $15 \mathrm{~min}$.

The membrane arrays were then scanned with an Epson Perfection 1670 flat bed scanner (Seiko Epson Corp., Naganoken, Japan). The intensity of spot image was quantified by using AlphaEase ${ }^{\circledR}$ FC software (Alpha Innotech Corp., San Leandro, CA, USA). The spot intensity of each gene marker was then normalized to that of $B$-actin to obtain the "expression

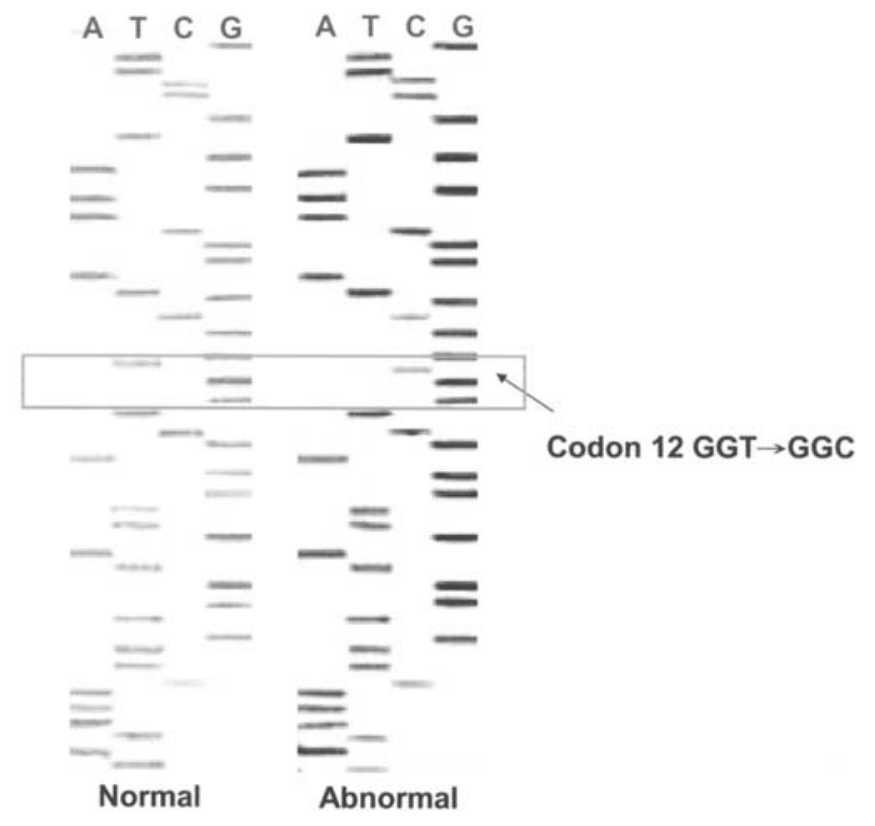

Figure 1. Representative examples of direct sequence analysis of K-ras mutation in patients with NSCLC. Sequencing gel, 5' (bottom) to 3' (top), shows a K-ras point mutation (GGT $\rightarrow$ GGC) at codon 12 in a patient with mutant K-ras, compared with the sequences in another NSCLC patient with wild-type K-ras.

ratio'. The normal expression ratio of a single gene was determined by calculating the mean expression ratio of the respective gene in the 20 healthy volunteers. Individual genes with an expression ratio 2-fold higher than the corresponding normal expression ratio were considered as 'positive' (overexpressed) using membrane array analysis. According to our previous study, the optimal threshold number of overexpressed (positive) markers using membrane array to define the test outcome was 11 . In other words, when $\geq 11$ or more of the 22 target genes were positive (overexpressed), the membrane array assay was defined as 'positive'.

Statistical analysis. All data were analyzed using the Statistical Package for the Social Sciences version 11.5 software (SPSS Inc., Chicago, IL). The $\chi^{2}$ test was used to analyze the correlation between membrane array results and the clinicopathological features of NSCLC patients. A P-value of $<0.05$ was considered to be statistically significant.

\section{Results}

Clinicopathological features of NSCLC patients. The mean age of the 76 NSCLC patients was 61 years (range, 37-87). Thirty-two were males and 44 were females. The histological subtypes in these NSCLC patients were as follows: 55 patients (72.4\%) had adenocarcinoma and 21 patients $(27.6 \%)$ had squamous cell carcinoma (28\%). According to the revised international system for staging lung cancer, 10 patients were at stage I $(\mathrm{a}+\mathrm{b}), 21$ at stage II $(\mathrm{a}+\mathrm{b}), 20$ at stage III $(\mathrm{a}+\mathrm{b})$, and 25 at stage IV.

Detection of K-ras mutations by direct sequencing. Direct sequencing was carried out to identify the mutations of K-ras 
Table III. Detection of K-ras mutations in 76 NSCLC patients by direct sequencing.

\begin{tabular}{|c|c|c|c|c|c|c|}
\hline \multirow[b]{2}{*}{ Characteristics } & \multirow[b]{2}{*}{ Case no. } & \multicolumn{5}{|c|}{ K-ras mutation } \\
\hline & & Codon 12 & Codon 13 & Codon 31 & Codon 61 & Total $(\%)$ \\
\hline All patients & 76 & 21 & 5 & 1 & 1 & $28(36.8)$ \\
\hline \multicolumn{7}{|l|}{ Sex } \\
\hline Female & 44 & 11 & 3 & 1 & & $15(34.1)$ \\
\hline Male & 32 & 10 & 2 & & 1 & $13(40.6)$ \\
\hline \multicolumn{7}{|l|}{ Smoking ${ }^{\mathrm{a}}$} \\
\hline Smoker & 35 & 17 & 1 & & & $18(51.4)$ \\
\hline Non-smoker & 41 & 4 & 4 & 1 & 1 & $10(24.4)$ \\
\hline \multicolumn{7}{|l|}{ Histology } \\
\hline $\mathrm{AC}$ & 55 & 15 & 4 & 1 & & $20(36.4)$ \\
\hline $\mathrm{SC}$ & 21 & 6 & 1 & & 1 & $8(38.1)$ \\
\hline
\end{tabular}

$\mathrm{AC}$, adenocarcinoma; SC, squamous cell carcinoma. ${ }^{\mathrm{a}} \mathrm{P}<0.05$.

in 76 patients with NSCLC. A representative example of direct sequence analysis, which demonstrated a point mutation $(\mathrm{GGT} \rightarrow \mathrm{GGC})$ at codon 12, was shown in Fig. 1. The results showed that $28(36.8 \%)$ of the 76 NSCLC patients had K-ras mutations. Codons 12 and 13 were the mutation hotspots. Twenty-one $(75 \%)$ of the 28 mutations were located at codon 12, and $5(17.8 \%)$ were located at codon 13 . K-ras mutations also occur at codons 31 and 61, each with one NSCLC patient. Regarding the histological types, 20 (36.4\%) of the 55 lung adenocarcinomas had K-ras mutations, with 15 at codon 12, 4 at codon 13 and 1 at codon 31. Eight (38.1\%) of the 21 squamous cell carcinomas had K-ras mutations, with 6 at codon 12,1 at codon 13 and 1 at codon 61. In addition, the K-ras mutation rate was higher in smokers than in non-smokers $(51.4 \%$ vs. $24.4 \%, \mathrm{P}=0.015)$. There were no significant differences in K-ras mutation rates between different sexes and histological types in NSCLC (Table III).

Detection of activated $K$-ras by membrane array. The peripheral blood samples from these 76 NSCLC patients were analyzed with our previously designed K-ras oncogene membrane array for the detection of K-ras activation. The interpretations of membrane array outcomes were based on our previous study. In other words, when $\geq 11$ of the 22 marker genes on membrane array were positive (overexpressed), the membrane array was determined to be 'positive'. In contrast, a membrane array assay with less than 11 positive markers was defined to be 'negative'. Representative images of membrane array are shown in Fig. 2. As a result, the membrane array could positively detect activated K-ras in 31 (40.8\%) of the 76 NSCLC patients, including 17 of the 44 females and 14 of the 32 males. The positive detection rates were similar for male and female NSCLC patients (38.6 vs. $43.8 \%, \mathrm{P}=0.654$ ), while being significantly higher in smokers than in non-smokers (57.1 vs. $26.8 \%, \mathrm{P}=0.009$ ). Regarding the histological types, $21(38.2 \%)$ of the 55 lung adenocarcinomas and $10(47.6 \%)$ of the 21 squamous cell carcinomas were detectable with K-ras activation by membrane array method. Although the positive
A

\begin{tabular}{|lllllllll|}
\hline ATP2A2 & ATP6VOB & BCL2 & CALM2 & CEBPB & MMP1 & COL4A1 & CXCL11 & CXCR4 \\
ATP2A2 & ATP6VOB & BCL2 & CALM2 & CEBPB & MMP1 & COL4A1 & CXCL11 & CXCR4 \\
ATP2A2 & ATP6VOB & BCL2 & CALM2 & CEBPB & MMP1 & COL4A1 & CXCL11 & CXCR4 \\
CYR61 & DVL3 & E2F4 & ETS1 & H2AFZ & L1CAM & LRP1 & RAP1B & RPL30 \\
CYR61 & DVL3 & E2F4 & ETS1 & H2AFZ & L1CAM & LRP1 & RAP1B & RPL30 \\
CYR61 & DVL3 & E2F4 & ETS1 & H2AFZ & L1CAM & LRP1 & RAP1B & RPL30 \\
SLC25A5 & SPP1 & TAF12 & TBX19 & Plant & Blank & Blank & Blank & $\beta$-actin \\
SLC25A5 & SPP1 & TAF12 & TBX19 & Plant & Blank & Blank & Blank & $\beta$-actin \\
SLC25A5 & SPP1 & TAF12 & TBX19 & Plant & Blank & Blank & Blank & $\beta$-actin \\
\hline
\end{tabular}

B

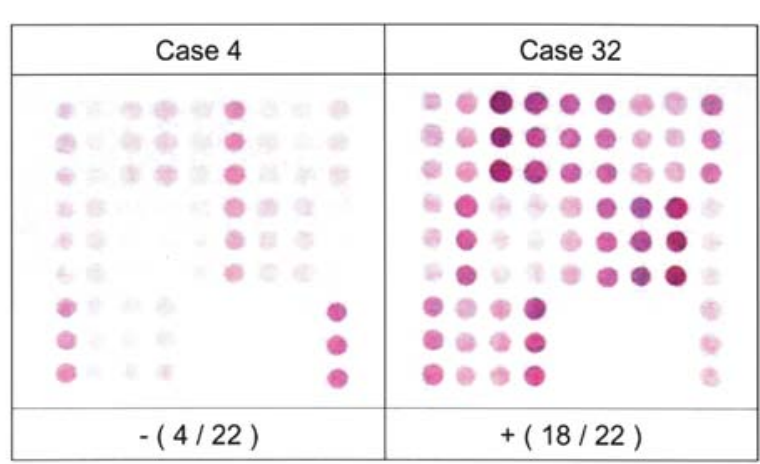

Figure 2. Membrane array assays. (a) Schematic representation of oligonucleotide probes on membrane array. (b) Representative images of membrane array assay. Briefly, each spot on membrane array represented an oligonucleotide probe. After being scanned, transformed into spot intensity, and normalized to the level of $\beta$-actin, the normalized intensity of each spot was converted to the expression ratio of a marker gene for statistical analysis. Individual markers with expression ratio 2 -fold higher than the corresponding normal expression ratio were determined to be 'positive' (overexpressed). Finally, a test with $\geq 11$ positive markers on membrane array was determined to be 'positive'. For instance, 18 of the 22 target genes were overexpressed in a NSCLC patient (case 18, with K-ras mutation in codon 12 by direct sequencing). Thus, this membrane array assay was determined to be 'positive'. On the other hand, only 4 of the 22 target genes were overexpressed in another NSCLC patient (case 4, without K-ras mutation by direct sequencing), thereby determined to be 'negative'.

detection rate was higher in squamous cell carcinomas than in adenocarcinomas, the difference did not reach a statistical 
Table IV. Detection of activated K-ras by membrane array and the correlations between activated K-ras and clinicopathological features in 76 NSCLC patients.

\begin{tabular}{|c|c|c|c|c|}
\hline \multirow[b]{2}{*}{ Characteristics } & \multirow[b]{2}{*}{ Case no. } & \multicolumn{3}{|c|}{ Activated K-ras } \\
\hline & & Positive (\%) & Negative & P-value \\
\hline All patients & 76 & $31(40.8)$ & 45 & \\
\hline Age, mean & 61 & 63 & 60 & \\
\hline Sex & & & & 0.654 \\
\hline Female & 44 & $17(38.6)$ & 27 & \\
\hline Male & 32 & $14(43.8)$ & 18 & \\
\hline Smoking & & & & $0.009^{\mathrm{a}}$ \\
\hline Smoker & 35 & $20(57.1)$ & 15 & \\
\hline Non-smoker & 41 & $11(26.8)$ & 29 & \\
\hline Histology & & & & 0.454 \\
\hline $\mathrm{AC}$ & 55 & $21(38.2)$ & 34 & \\
\hline $\mathrm{SC}$ & 21 & $10(47.6)$ & 11 & \\
\hline Overall stage & & & & 0.648 \\
\hline Stage I & 10 & $3(30)$ & 7 & \\
\hline Stage II & 21 & $7(33.3)$ & 14 & \\
\hline Stage III & 20 & $9(45)$ & 11 & \\
\hline Stage IV & 25 & $12(48)$ & 13 & \\
\hline
\end{tabular}

$\mathrm{AC}$, adenocarcinoma; SC, squamous cell carcinoma. ${ }^{\mathrm{a}} \mathrm{P}<0.05$.

Table V. Histological subgroup analysis of the correlations between smoking and activated K-ras.

Activated K-ras

Characteristics Case no. Positive (\%) Negative P-value

\begin{tabular}{lrrrrr}
\hline Histology & & & & & \\
AC & 55 & $21(38.2)$ & 34 & \\
Smoker & 23 & $13(56.5)$ & 10 & $0.017^{\mathrm{a}}$ \\
Non-smoker & 32 & $8(25)$ & 24 & \\
SC & 21 & $10(47.6)$ & 11 & \\
Smoker & 12 & $8(66.7)$ & 4 & $0.043^{\mathrm{a}}$ \\
Non-smoker & 9 & $2(22.2)$ & 7 & \\
\hline
\end{tabular}

AC, adenocarcinoma; SC, squamous cell carcinoma. ${ }^{\mathrm{a} P}<0.05$.

significance $(\mathrm{P}=0.454)$. As we analyzed the correlations between the results of membrane array assays and the pathological stages of NSCLC patients, we found a trend that the detection rates were higher when the patients were at more advanced stages. However, the difference did not reach a statistical significance $(\mathrm{P}=0.648)$ (Table IV).

In the histological subgroup analysis of the correlation between smoking and activated K-ras, we found that smoking
Table VI. Correlation between the results of direct sequencing and membrane array analysis for detection of K-ras oncogene.

\begin{tabular}{|c|c|c|c|}
\hline & \multirow[b]{2}{*}{ Case no. $(\%)$} & \multicolumn{2}{|c|}{ Membrane array } \\
\hline & & Positive & Negative \\
\hline \multicolumn{4}{|c|}{$\begin{array}{l}\text { K-ras mutation by } \\
\text { direct sequencing }\end{array}$} \\
\hline Positive & $28(36.8)$ & 27 & 1 \\
\hline Negative & 48 (63.2) & 4 & 44 \\
\hline \multicolumn{4}{|c|}{ Mutation site } \\
\hline Codon 12 & 21 & 21 & 0 \\
\hline Codon 13 & $5(17.8)$ & 5 & 0 \\
\hline Codon 31 & $1(3.6)$ & 0 & 1 \\
\hline Codon 61 & 1 (3.6) & 1 & 0 \\
\hline
\end{tabular}

is associated with more frequent activated K-ras not only in lung adenocarcinomas (56.5\% in smokers vs. $25 \%$ in nonsmokers, $\mathrm{P}=0.017$ ) but also in lung squamous cell carcinomas (66.7\% in smokers vs. $22.2 \%$ in non-smokers, $\mathrm{P}=0.043$ ) (Table V).

Comparisons between the results by direct sequencing and membrane array. The correlations between the detections of $\mathrm{K}$-ras oncogene by direct sequencing and membrane array were further explored. Our results demonstrated that detections of K-ras oncogene by these two methods were comparable. Among the 28 patients with K-ras mutations, 27 were positively detected by membrane array. In detail, all the 27 patients with K-ras mutations at codons 12,13 and 61 were positive on membrane array assays, while the only one patient with K-ras mutation at codon 31 was negative on membrane array assay. In addition, 4 of the 48 patients without K-ras mutations were also positively detected for activated K-ras by membrane array method (Table VI).

\section{Discussion}

Direct sequencing analysis of K-ras mutation in our study showed that $36.8 \%$ of Taiwanese NSCLC patients have K-ras mutations. Seventy-five percent of the K-ras mutations occurred at codon 12 and $17.9 \%$ at codon 13 . There was no significant difference between males and females. These results are consistent with other previous studies reporting the mutations of K-ras in other countries. Noteworthily, the frequency of K-ras mutation of lung squamous cell carcinomas in our study was comparable with that of lung adenocarcinomas. This is somewhat different from other reports that K-ras mutations are specific for adenocarcinomas. However, it is not a novel finding that K-ras mutations can play a role in the development of adenocarcinomas as well as of squamous cell carcinomas. In a study examining mutational pattern of K-ras among 27 Chinese lung cancer patients (20), K-ras mutations were found in 7 (54\%) of 13 squamous cell carcinoma and 5 (42\%) of 12 adenocarcinoma (AC) patients. In a larger study by Dr Vachtenheim J in the Czech Republic (21), K-ras 
mutation was found in $17(12 \%)$ of the 118 lung squamous cell carcinomas and 7 (37\%) of 19 lung adenocarcinomas. Further studies investigating the associations between the environmental factors and K-ras mutations in lung squamous cell carcinomas are needed to clarify such geographic differences.

Exposure to carcinogenic agents in tobacco smoke proved to be an important factor in the induction of point mutations in K-ras in human lung cancers. Studies have shown that the $\mathrm{K}$-ras mutations in NSCLC were more frequently found in smokers $(25-43 \%)$ than in non-smokers $(0-8.7 \%)(5,6,22,23)$. Our study demonstrated a similar result showing that the $\mathrm{K}$-ras oncogene was more frequently found in smokers than in non-smokers, either using direct sequencing or the membrane array method. Analysis of the correlation between smoking and K-ras mutations demonstrated that $51.4 \%$ of the smokers had K-ras mutation, compared with only $24.4 \%$ in nonsmokers. We also found that most of the K-ras mutations in smokers were located at codon 12 , with only one exception that occurred at codon 13. On the contrary, the locations of $\mathrm{K}$-ras mutation in non-smokers were equally distributed at codons 12 and 13, each with four patients. Moreover, the two NSCLC patients with K-ras mutations at codons 31 and 61 were both non-smokers. Our findings suggest a strong correlation between smoking and K-ras mutation at codon 12 , which is consistent with previous reports $(6,24)$. In the histological subgroup analysis of the correlation between smoking and activated K-ras, we found that the smoking status is associated with more frequent activated K-ras not only in lung adenocarcinomas but also in lung squamous cell carcinomas. This indicates that smoking may also play a role in the induction of K-ras mutation in lung squamous cell carcinomas.

Another interesting finding of our results is the higher detection rate of K-ras oncogene in non-smokers than that of others. The racial, geographic and environmental differences in carcinogenesis of NSCLC may explain this finding. The high incidence and mortality of lung cancer in Chinese women despite a low smoking prevalence have led to extensive research in other cultural and environmental factors, including indoor pollution, diet and infections. Studies have confirmed the exposure to cooking oil fumes as a risk factor for lung cancer in Taiwanese women $(25,26)$. Another study by Cheng et al reported a strong association of human papillomavirus $16 / 18$ infection with lung cancer in non-smoking Taiwanese women (27). However, further studies are needed to determine whether these factors could act like tobacco smoke in the activation of K-ras and their mechanisms.

In the present study, we also detected gene overexpression specific for activated K-ras in 76 NSCLC patients by using the membrane array method. When compared with the detection of K-ras mutations by direct sequencing, the K-ras oncogene membrane array is so sensitive that all the 27 patients with K-ras mutations at codon $12,13,61$ were positively detected. Moreover, 4 of the 48 patients without K-ras mutations were also positively detected for activated K-ras by the membrane array method. This result is compatible with previous evidence that K-ras may still play a role in oncogenesis in the absence of activating mutation. A patient with K-ras mutation at codon 31 was negative for the membrane array assay. This indicates that a mutation of K-ras at codon 31 does not activate the $\mathrm{K}$-ras pathway but its biological significance is unclear and in need of further study.

The ability to detect K-ras oncogene may have a great influence in the management of NSCLC patients, including early detection, risk stratification and therapeutic guidance. K-ras could serve as a molecular marker for early diagnosis of lung cancer (28-30). Studies using different methods have successfully detected K-ras oncogene in sputum and bronchioalveolar lavage fluid samples from NSCLC patients with a detection rate of $25-48 \%$ (31-34). Although the predicting values of K-ras in the prognosis of NSCLC are somewhat conflicting, two meta-analysis studies confirmed that the presence of K-ras mutations is associated with a worse survival in NSCLC patients $(8,9)$. In addition, studies have shown that mutations in K-ras were associated with a lack of sensitivity to Gefitinib or Erlotinib (35), and a poorer clinical outcome when an NSCLC patient was treated with Erlotinib and chemotherapy (36). As more and more evidence suggests that molecular markers appear in blood via tumor shedding or circulating cancer cells even at the early stage of cancer, the peripheral blood provides a reliable and more convenient clinical sample for molecular diagnosis of lung cancer. In the present study, the membrane array detected K-ras oncogene in the peripheral blood in all of the 27 NSCLC patients with K-ras mutations at codons 12,13 and 61 in their tumor tissues. We believe this K-ras oncogene membrane array has greater potential for clinical applications than other previous methods.

In conclusion, $36.8 \%$ of NSCLC patients in Taiwan have $\mathrm{K}$-ras mutations with hotspots at codons 12 and 13. The incidences of K-ras mutation in the subgroups of non-smokers and squamous cell carcinomas are relatively higher in Taiwan than in other countries. Our K-ras oncogene membrane array which positively detected circulating activated K-ras in all the NSCLC patients with K-ras mutations at codons 12, 13 and 61 has a great potential for clinical application.

\section{References}

1. Jemal A, Siegel R, Ward E, Murray T, Xu J, Smigal C and Thun MJ: Cancer statistics 2006. CA Cancer J Clin 56: 106-130, 2006.

2. Friday BB and Adjei AA: K-ras as a target for cancer therapy. Biochim Biophys Acta 1756: 127-144, 2005.

3. Rodenhuis S: ras and human tumors. Semin Cancer Biol 3: 241-247, 1992.

4. Rodenhuis S, van de Wetering ML, Mooi WJ, Evers SG, van Zandwijk N and Bos JL: Mutational activation of the K-ras oncogene. A possible pathogenic factor in adenocarcinoma of the lung. N Engl J Med 317: 929-935, 1987.

5. Rodenhuis S and Slebos RJ: Clinical significance of ras oncogene activation in human lung cancer. Cancer Res 52: S2665-S2669, 1992.

6. Slebos RJ, Hruban RH, Dalesio O, Mooi WJ, Offerhaus GJ and Rodenhuis S: Relationship between K-ras oncogene activation and smoking in adenocarcinoma of the human lung. J Natl Cancer Inst 83: 1024-1027, 1991.

7. Rodenhuis S, Slebos RJ, Boot AJ, Evers SG, Mooi WJ, Wagenaar SS, van Bodegom PC and Bos JL: Incidence and possible clinical significance of K-ras oncogene activation in adenocarcinoma of the human lung. Cancer Res 48: 5738-5741, 1988.

8. Huncharek M, Muscat J and Geschwind JF: K-ras oncogene mutation as a prognostic marker in non-small cell lung cancer: a combined analysis of 881 cases. Carcinogenesis 20: 1507-1510, 1999. 
9. Mascaux C, Iannino N, Martin B, Paesmans M, Berghmans T, Dusart M, Haller A, Lothaire P, Meert AP, Noel S, Lafitte JJ and Sculier JP: The role of RAS oncogene in survival of patients with lung cancer: a systematic review of the literature with meta-analysis. Br J Cancer 92: 131-139, 2005.

10. Hsu CY, Bristow R, Cha MS, Wang BG, Ho CL, Kurman RJ, Wang TL and Shih I: Characterization of active mitogenactivated protein kinase in ovarian serous carcinomas. Clin Cancer Res 10: 6432-6436, 2004

11. Von Lintig FC, Dreilinger AD, Varki NM, Wallace AM, Casteel DE and Boss GR: Ras activation in human breast cancer. Breast Cancer Res Treat 62: 51-62, 2000.

12. Galiana C, Lozano JC, Bancel B, Nakazawa $H$ and Yamasaki H: High frequency of Ki-ras amplification and p53 gene mutations in adenocarcinomas of the human esophagus. Mol Carcinog 14: 286-293, 1995.

13. Coleman WB, Throneburg DB, Grisham JW and Smith GJ: Overexpression of c-K-ras, c-N-ras and transforming growth factor beta co-segregate with tumorigenicity in morphologically transformed C3H 10T1/2 cell lines. Carcinogenesis 15: 1005-1012, 1994.

14. Lin SR, Tsai JH, Yang YC and Lee SC: Mutations of K-ras oncogene in human adrenal tumours in Taiwan. Br J Cancer 77: 1060-1065, 1998.

15. Chen YF, Chiu HH, Wu CH, Wang JY, Chen FM, Tzou WH, Shin SJ and Lin SR: Retinoblastoma protein (pRB) was significantly phosphorylated through a Ras-to-MAPK pathway in mutant $\mathrm{K}$-ras stably transfected human adrenocortical cells. DNA Cell Biol 22: 657-664, 2003.

16. Lin SR, Hsu CH, Tsai JH, Wang JY, Hsieh TJ and Wu CH: Decreased GTPase activity of K-ras mutants deriving from human functional adrenocortical tumours. Br J Cancer 82: 1035-1040, 2000.

17. Chen YF, Wang JY, Wu CH, Chen FM, Cheng TL and Lin SR: Detection of circulating cancer cells with K-ras oncogene using membrane array. Cancer Lett 229: 115-122, 2005.

18. Mountain CF: Revisions in the International System for Staging Lung Cancer. Chest 111: 1710-1717, 1997.

19. Sambrook J, Fritsch EF and Maniatis T: Molecular cloning: a laboratory manual. In: Ford N and Nolan C (eds). Cold Spring Harbor Laboratories Press, NY, pp6.22-6.34, 1989.

20. Gao HG, Chen JK, Stewart J, Song B, Rayappa C, Whong WZ and Ong T: Distribution of p53 and K-ras mutations in human lung cancer tissues. Carcinogenesis 18: 473-478, 1997.

21. Vachtenheim J, Horakova I, Novotna H, Opaalka P and Roubkova H: Mutations of K-ras oncogene and absence of H-ras mutations in squamous cell carcinomas of the lung. Clin Cancer Res 1: 359-365, 1995.

22. Gealy R, Zhang L, Siegfried JM, Luketich JD and Keohavong P: Comparison of mutations in the p53 and K-ras genes in lung carcinomas from smoking and non-smoking women. Cancer Epidemiol Biomarkers Prev 8: 297-302, 1999.

23. Ahrendt SA, Decker PA, Alawi EA, Zhu Yr YR, SanchezCespedes M, Yang SC, Haasler GB, Kajdacsy-Balla A, Demeure MJ and Sidransky D: Cigarette smoking is strongly associated with mutation of the K-ras gene in patients with primary adenocarcinoma of the lung. Cancer 92: 1525-1530, 2001.
24. Westra WH, Slebos RJ, Offerhaus GJ, Goodman SN, Evers SG, Kensler TW, Askin FB, Rodenhuis S and Hruban RH: K-ras oncogene activation in lung adenocarcinomas from former smokers. Evidence that K-ras mutations are an early and irreversible event in the development of adenocarcinoma of the lung. Cancer 72: 432-438, 1993.

25. Ko YC, Cheng LS, Lee CH, Huang JJ, Huang MS, Kao EL, Wang HZ and Lin HJ: Chinese food cooking and lung cancer in women non-smokers. Am J Epidemiol 151: 140-147, 2000.

26. Ko YC, Lee CH, Chen MJ, Huang CC, Chang WY, Lin HJ, Wang HZ and Chang PY: Risk factors for primary lung cancer among non-smoking women in Taiwan. Int J Epidemiol 26: 24-31, 1997.

27. Cheng YW, Chiou HL, Sheu GT, Hsieh LL, Chen JT, Chen CY, $\mathrm{Su} \mathrm{JM}$ and Lee $\mathrm{H}$ : The association of human papillomavirus 16/18 infection with lung cancer among non-smoking Taiwanese women. Cancer Res 61: 2799-2803, 2001.

28. Destro A, Bianchi P, Alloisio M, Laghi L, Di GS, Malesci A, Cariboni U, Gribaudi G, Bulfamante G, Marchetti A, Bosari S, Infante M, Ravasi $\mathrm{G}$ and Roncalli M: K-ras and p16(INK4A) alterations in sputum of NSCLC patients and in heavy asymptomatic chronic smokers. Lung Cancer 44: 23-32, 2004.

29. Keohavong P, Lan Q, Gao WM, Zheng KC, Mady HH, Melhem MF and Mumford JL: Detection of p53 and K-ras mutations in sputum of individuals exposed to smoky coal emissions in Xuan Wei County, China. Carcinogenesis 26: 303-308, 2005.

30. Minamoto T, Mai M and Ronai Z: K-ras mutation: early detection in molecular diagnosis and risk assessment of colorectal, pancreas and lung cancers - a review. Cancer Detect Prev 24: 1-12, 2000.

31. Nakajima E, Hirano T, Konaka C, Ikeda N, Kawate N, Ebihara Y and Kato H: K-ras mutation in sputum of primary lung cancer patients does not always reflect that of cancerous cells. Int $\mathbf{J}$ Oncol 18: 105-110, 2001.

32. Ronai Z, Yabubovskaya MS, Zhang E and Belitsky GA: K-ras mutation in sputum of patients with or without lung cancer. J. Cell Biochem Suppl 25: S172-S176, 1996.

33. Zhang LF, Gao WM, Gealy R, Weissfeld J, Elder E, Whiteside TL and Keohavong P: Comparison of K-ras gene mutations in tumour and sputum DNA of patients with lung cancer. Biomarkers 8: 156-161,2003.

34. Ahrendt SA, Chow JT, Xu LH, Yang SC, Eisenberger CF, Esteller M, Herman JG, Wu L, Decker PA, Jen J and Sidransky D: Molecular detection of tumor cells in bronchoalveolar lavage fluid from patients with early stage lung cancer. J Natl Cancer Inst 91: 332-339, 1999.

35. Pao W, Wang TY, Riely GJ, Miller VA, Pan Q, Ladanyi M, Zakowski MF, Heelan RT, Kris MG and Varmus H: KRAS mutations and primary resistance of lung adenocarcinomas to gefitinib or erlotinib. PLoS Med 2: E17, 2005.

36. Eberhard DA, Johnson BE, Amler LC, Goddard AD, Heldens SL, Herbst RS, Ince WL, Janne PA, Januario T, Johnson DH, Klein P, Miller VA, Ostland MA, Ramies DA, Sebisanovic D, Stinson JA, Zhang YR, Seshagiri S and Hillan KJ: Mutations in the epidermal growth factor receptor and in KRAS are predictive and prognostic indicators in patients with non-small-cell lung cancer treated with chemotherapy alone and in combination with erlotinib. J Clin Oncol 23: 5900-5909, 2005. 